Henri Michaux died in 1984 at the age of eighty-five. He was the author of more than thirty books of poems, prose poems, narratives, essays, journals, and drawings; his writings were translated into more than half a dozen languages, his paintings amply displayed in the major art centers of Europe and the United States. His place in world literature and art was secure, but difficult to define. Michaux stood alone.

When people who know his work try to relate Michaux to some movement or tradition, they don't come up with schools of poets, but with a range of great individual figures in literature and art: Kafka, Hieronymus Bosch, Goya, Swift, Paul Klee, Rabelais.... His strangeness has occasionally led him to be classified with the Surrealists (some critics feel they have to put him somewhere), but he never used their techniques: no cadavre exqu1s, no free association, no abstractly formulated attempt to destroy tradition and logic. A sentence like André Breton's "The color of fabulous salvations darkens even the slightest death-rattle: a calm of relative sighs" could never have been written by Michaux, ${ }^{1}$ who tries to render his dangerous, magical world as clearly and concretely as possible. Whether in poetry, prose, India ink, or paint, his weird visions are not the result of some theory about the nature of art: they are messages from his inner space. In a sense he inhabits the realm the Surrealists merely longed for. ${ }^{2}$

No group, no label for him. John Ashbery defined him as "hardly a painter, hardly even a writer, but a conscience - the most sensitive substance yet discovered for registering the fluctuating anguish of day-to-day, minute-to-minute living." Wild and druggy enough to be venerated in the sixties by a poet like Allen Ginsberg (he called Michaux "master" and "genius"), and by the French rap star M.C. Solaar in the nineties, an inventor of fictions brilliant enough to be admired by Jorge Luis Borges ("his work is without equal in the literature of our time"), who was Henri Michaux?

His own "Some Information about Fifty-Nine Years of Existence" is a good place to start looking for an answer, although there are aspects of the man one could not possibly guess from that text. For example, although he was a very private person (he had a real horror of being photographed), he did have a circle of friends--particularly literary and artistic friends-and was an extremely courteous man. ${ }^{3}$ Some of the dates in the "Information ...' are wrong; the picture given is not only fragmentary and mythically literary 
(the poet as Outsider), but shifting and evasive; thus in 1935, we find this utterly maladjusted rebel (as Michaux has depicted himself) editing a literary review; something is wrong with this picture.

"Some Information about Fifty-Nine Years of Existence" is a highly personal, expressive account of his life to $195^{8}$, based on how Michaux saw himself and what he knew; in actual fact, it answers the question "Who am I?" the way autobiographical fictions do. ${ }^{4}$ Perhaps the best way of getting an account of his work will be through a reader's fiction-a narrative, not of events in a life, but of the fundamental project in a work, based on what I know about Michaux and how I see him.

Let's say that from early childhood on, a man feels - more than most people do-how fragile he is, how hollow and weak ("I was born full of holes . . I admit it, I'm an enclosed hollow . . . I built myself on an absent column"), encumbered by the world around him ("It began when I was a child. There was a big adult in the way"); ${ }^{5}$ he feels, too, how mobile and changing he is (who am I? this one? that one?), but he doesn't try to get rid of the feeling; on the contrary, he asserts its value:

we are not made for just one self. We are wrong to cling to it. The prejudice for unity. (Here as elsewhere, the will: impovenshing and sacrificing.)

( . . . ) There is not one self. There are not ten selves. There is no self. ME is nothing but a position in equilibrum.

(Afterword to Plume, 1938)

He refuses to freeze himself into one adult identity, one way of being in the world ("Adult-finished - dead: nuances of the same state"); refuses to act, for stability or profit ("He who rejects the world builds no house in it"). He travels, both spatially (Ecuador, 1929; A Barbarian in Asia, 1933) and mentally (Elsewhere, 1 948; etc.), but he travels precisely to get away from what "they" want. As he himself said, he traveled in order to "drive his country out of him, his attachments of all kinds and whatever elements of Greek or Roman culture or Belgian habits have become attached to him, despite himself. He travels against" ("Some Information ... ') ). He rejects traditional Western education, philosophy, ${ }^{6}$ art, and music:

Books are boring to read. You can't move around in them as you wish. You are asked to follow. The trail is traced, one way.

$$
\text { ("Reading," 1950, in Passages) }
$$


Heard Spanish music yesterday. Tells me nothing. Music for entertainment. What I want ... is music to question, to auscultate, to approach the problem of being.

("Furst Impressions," 1949, in Passages)

He also feels intense anxiety, "the obsessive beacon of fear," rage, and above all, "fatigue, fatigue" . . What will become of him?

One obvious possibility is that he will be defined as hopelessly neurotic, or insane, and paralyzed - by himself or by others (they might lock him up). But this man has unusual verbal and visual gifts, and a still more unusual gift for hanging on to what he is, going with it, exploring it. It seems to him that the danger lies in not doing so: "he who hides his madman dies voiceless;" or conversely, "whoever rejects his demons badgers us to death with angels." With this in mind, he begins to write and to paint.

Without the slightest concern for realism, or sur-realism, ${ }^{8}$ or for any literary fashion, he produces strange little fables, "apparitions" in poetry or prose or paint, ${ }^{10}$ pictures of fantastic predicaments and fantastic inventions and desires, coldly objective descriptions of strange voyages (both real and imagined), and above all "Exorcisms," ${ }^{11}$ maledictions, and other "poetry for power" (Michaux's title)—poems in strongly rhythmic, "hammering" free verse. It is here that we can see most clearly what he is about:

Exorcism, a reaction in force, with a battering ram, is the true poem of the prisoner.

In the very space of suffering and obsession, you introduce such exaltation, such magnificent violence, welded to the hammering of words, that the evil is progressively dissolved, replaced by an airy demonic sphere-a marvelous state!

(Preface to Ordeals, Exorcisms, 1945)

These are truly magical works for Michaux (and for many readers): like the art of "primitive" peoples, they are primarily produced to accomplish something, "to ward off the surrounding powers of the hostile world."

Of course the "magic" of these poems depends on the way the poet uses words, as he himself explicitly recognizes for at least one of their forms: "As for the magic of malediction, it is, above all, hammering, hammering, hammering." But in a sense, all Michaux's work does not seem to aim at being fine art. He has a fundamental distrust of beautiful 
language, indeed of any language. His writing is not aesthetic (in his view) but performative. His art aims at showing what he sees, at channeling evil energy and dealing with it. He deals with it through the work. "I write so that what was true should no longer be true. Prison displayed is prison no longer." Perhaps this can help others as it helps him:

I wrote My Properties out of hygiene . . . for my health . . . this book, this experiment which seems to have been born entirely from egotism-I would venture to say it is social . . . an operation within everyone's reach . . .

To all those suffering, involuntarily, from their imaginations-I would like to have been useful to them in this way, at least.

(Afterword to My Properties, 1934)

And in fact his work is recognized, admired, first by a few, then by many.

As he becomes more famous, he is asked to reflect, publicly, on his work and the world, and he does so in essays and poetic aphorisms. Above all he continues to delve into the repressed side of Western consciousness and art - the eerie mobility and fragmentation of the self-using words, paint and ink and pencil, and, for a period of about ten years, hallucinogenic drugs.

He also explores what is unacceptable in other ways: tentative, private, unfinished. Take this little passage from an essay on music:

There is an instrument that can hardly be heard; it is played in Africa for oneself alone, inside the hut, or outside without bothering or attracting anyone. Rudimentary, archaic, apparently put together haphazardly, freely, by the village blacksmith, the sanzas (that is its name): no two the same, no good even for a slightly elaborated melody, it is independent of any scale.

Anarchical. A music of murmurs, the opposite of music for competitions, compositions. Instrument to relieve us dreamily from all the nossemakers of this world.

("In the Changing Waters of Resonance," Facing the Vanishing World, 1975)

This description, and valorization, of an object may be read as a delicate metaphor for a system of values far removed from the norm. Who but Michaux would want an instrument that can't even play a melody? Toward the end of his life, working from the model of Chinese ideograms, he even dreams of a language of pure lines that would communicate 
intimately or "murmur," without forming any ideas too definitely: down with our swaggering languages, with their rigid, enslaving syntax and grammar! Let's have no alphabet-no words. ${ }^{12}$

In one sphere of activity, he can function in this mode fairly eásily and does so all his adult life; he paints.

Born, raised, educated in a purely verbal environment and culture (and before the era of the invasion of images) I paint to decondition myself

(Emergences-Résurgences, 1972)

Obviously, for a poet, such "deconditioning" cannot always be nonverbal. But it can be nonrational and non-Western, not limited by the categories that we traditionally impose on consciousness. Increasingly, he explores mystical experience, Eastern religions; until his death he strives, in poetry and prose, painting and music, to "coincide with [him]self," to "'occupy [him]self," to achieve some kind of mobile, resolutely nonrational integration of his experience and consciousness, to integrate The Space $W_{1 t h}$ and the space without. ${ }^{13}$

MICHAUX AND "THE PROBLEM OF BEING": FACING THE WORST

In a famous aphorism, Pascal wrote that "all the unhappiness of men comes from one thing: which is not to be able to remain at rest in a room" - - hence, for Pascal, our frantic activity (divertissement) in the world. Michaux stays in the room and faces the unhappiness.

Under the low ceiling of my little bed-room is my night, a deep abyss.

Constantly hurled down to a depth of thousands of feet, with a gulf several times that big below me, I hang on by the rough-spots with the greatest difficulty, dead tired, mechanically...

("The Night Moves")

It is terrifying to confront the mobile, isolated self, and especially terrifying to face its fragility. Here is a Meidosem, one of the many fantastic beings the poet invented:

pierced by a thousand little transversal flows from extravasated blood bursting the arterioles, but it's not blood, it's the blood of memories, of the pierced soul .... it's the reddened water of useless memory flowing out 
. . through small passages leakng all over-minuscule, multuple punctures.

A Meidosem bursts. A thousand small veins of his faith in himself burst.

That which is physically closest to one's self, most expressive of it, is also fragile: Michaux is obsessed by the vulnerability of the human face. (Surely his horror of being photographed has something to do with this; so do the many faceless portraits he produced.) In a typical show in "The Land of the Hacs," "the noble features-noble as even the most ignoble are-the features of that face were trampled on like some unimportant sugar-beet." And "In the Land of Magic,"

offenders caught in the act have their faces ripped off on the spot, [leaving] a huge, round, scabby clot; $(\ldots)$

Anybody who has seen one will remember it forever. He has his nightmares to remember it with.

So the self can be stripped of its "face," its individual being, or it can hemorrhage out catastrophically. It can also be engulfed, as in the last sentence of "Space of the Shadows," or invaded: in "A Few Days of My Life among the Insects" the narrator has a hard time fending off a "huge female ichneumon-fly" who insists on sinking her egg-bearing rod into his kidneys "so as to pour out her abundant eggs, which I would then have had to nourish for months at a time, fetid victorious larvae." The horror is intensified by the monstrously unnatural sexual image: the male narrator is in danger of being raped and impregnated by a female insect.

Sexuality is not only monstrous "Among the Insects" (where the narrator also has intercourse with giant caterpillars). In a more ordinary world, five hideous women, one of them "A Mother of Nine," rape Michaux's character, Plume, until the blood flows. If they're in a bad mood, the giant female courtesans in "The Land of Magic" can "rip your head off in a flash, like a young herring's." The terrifying mobility of the self is matched by its weakness; its imminent destruction (self-destruction, in fact) is both horrifying and erotically attractive.

As the poet himself realizes, such a self creates monsters: "It soon became clear (from my adolescence on) that I had been born to live among monsters." In fact "with inner vision," he explores the actual lobe in his brain where they are produced: "The Monster Lobe." Indeed his texts swarm with monsters: not only "real" ones specifically called "monsters," which he meets everywhere (in his room, or on the stairs), but monstrous 
beings of all kinds. They may be monstrous in shape, like the "Pourpianes with green, quivering anuses" - here as elsewhere, the grotesque erotic detail recalls Hieronymus Bosch-or monstrous in size, like the giants mentioned above or the midget oak (see below); "Dwarves are born continually," says another narrator.

The creation of monsters is the clearest manifestation of what Freud, in his essay of that name, called the Unhermliche, the "uncanny,"14 a complex of emotions that other psychoanalysts have called "the Not-me," the surging up of all the negative energies excluded from the ordinary self or the ego. It is the eerie, frightening feeling the universe may sometimes inspire in anyone, the flip side of religious awe. The word uncanny has, of course, etymological connotations of the un-known in English; in German, Unheimliche suggests what is un-homelike or un-familiar. Freud makes much of this, for it comes from the repression of what is all too familiar-of what one cannot live with. And in fact the universe is an unlivable place for Michaux. How can he survive in it?

The first condition is: knowledge. Poetry and painting are paths to that knowledge. So are drugs. In I 954, ${ }^{15}$ after hesitating for a while, Michaux accepted the invitation of some friends (among them a neurologist) to experiment with mescaline, the active substance in the cactus used by certain Native American peoples to induce religious visions. Here Gilbert Lascault shrewdly points out that for Michaux — who, far from being a druggie, was rather "the water-drinking type" (as he himself says) - everything is a drug: fatigue, coffee, abstinence, even the effort at lucidity. All mescaline does is to show the poet what he is and has always desired. What he finds in mescaline, no doubt because it fascinates him, is not an escape from his anguish but a kind of "artificial hell" "16 in which anguish and loss of self dominate. He certainly doesn't use it for kicks: "Should one speak of pleasure? It was unpleasant," he writes in $195^{6}$ at the beginning of Miserable Mracle, his first book on mescaline. And in the epigraph to his third mescaline book, 1961:

Drugs bore us with their paradises. Let them give us a little knowledge instead. This is not a century for paradise.

(Knowledge through the Abyss)

With irrefutable, painful clarity, mescaline reveals to the poet that terrifying mobility, weakness, passivity, and tendency to dissolve which he had previously explored in fantasy. Passages like this one are typical in Miserable Miracle:

I myself was a torrent, I was drowned, I was navigation. My great constitution hall, my ambassador's hall, my hall for gifts and exchanges into which I 
usher foreigners for a first examination-1 had lost all my halls with my servants. I was alone, shaken around violently like a dirty thread in an energetic wash.

In "Space of the Shadows," a somber narrative written a few years before the experiments with hallucinogens, the nature of space itself (a "horrible inside-outside") presents constant dangers to the female speaker. In Turbulent Infinity (1957), Michaux's second book describing his mescaline experiences, he himself is "Fluid, inside fluids. Dwelling lost. Have become outside oneself.",

In one of the experiments related in Miserable Miracle, Michaux accidentally took an overdose and actually experienced the total destruction of his self (fortunately temporary). One of the ways he describes this ineffable experience ("so absolutely horrible ... I can't find any way of saying it and I feel like a counterfeiter when I try") is by this image:

incredibly fast, hundreds of lines of force were combing my being, which never managed to pull itself back together fast enough, which at the moment of coming back together was raked by a new row of tines, and then again, and then again

The feeling of speed and now infinite mobility are heightened elements of Michaux's ordinary sense of being. This leads him to recall

\begin{abstract}
that very remarkable look of those wild-haired madwomen, not only the wind makes them look that way or their wandering hands, or their helplessness, but the imperative inner necessity of translating (at least in that way) the rapid, infernal combing-uncombing of therr being-martyrized, penetrated, drawn out like wires, indefinitely.
\end{abstract}

So mescaline puts the poet in contact with the feelings of those for whom the universe is totally unlivable: the insane. Later, when he has abandoned drugs and their dangers (overdose and especially addiction), he will take a less dramatic path to such knowledge; when he writes about drawings of hospitalized mental patients in "Ravaged People" ( 1976 ), it feels as if he is picturing madness from within. 
There is another precondition for survival in Michaux's "room." Bad feelings must not be repressed, but intensified and pushed to their logical conclusions. The "logic" is not that of physical laws, but of mental reality; Freud would call it the primary process at work. Revolt is essential:

In my night, I besiege my Kıng, I get up little by little and I wring his neck.

He regains his strength, I come back at him and wring his neck again.

('My King")

So is destructive rage. Michaux recognizes clearly enough that the "holes" that make up his very being, the "absent column" on which he has "built [him]self," are filled with "a wind, an emptiness" of "hate"; in fact, he says, "this is my health" ("I Was Born Full of Holes," in Ecuador, 1929). Thus, in daily life and in his "room":

I can rarely see someone without beating him. Others prefer interior monologue. Not me. I prefer beating.

('My Occupations")

You can say what you like, my darlings, but I do know how to have a good time. Only yesterday, I ripped an arm off a policeman. ( . . . )

My sheets are just about never white. It's a good thing blood dries fast.

How could I sleep if it didn't?

("The Nıght Moves")

On the other hand, utter inattention to the worst catastrophes can be a great help:

Stretching his hands out from the bed, Plume was surprised not to encounter the wall. "Hmm!' he thought, "The ants must have eaten it . . " and he went back to sleep.

("Plume")

In the last analysis, Plume's creator resembles his Meidosems: "clamped to their weakness, strong in a sense because of it, invincible even ..." And as these last excerpts 
suggest, reading Michaux is not only a scary trip through the Unheimliche and the world of madness: it is a comic adventure.

\section{HUMOR AND TERROR}

Michaux survives, we smile. It's not surprising. The essence of what the Surrealists called humour norr, its "sublimity," as they said, lies in "the triumph of narcissism, in the invulnerability of the ego. . . . The ego refuses to let itself be injured . . . refuses to admit that traumas from the outside world can touch it." 17 The greater the trauma, the greater the triumph.

Surely that's what happens when we read "The Heroic Age," for example:

The Grant Barabbo, in play, ripped an ear off his brother Poomappi.

Poomappi said nothing, but as if absentmindedly he squeezed Barabbo's nose and the nose came off.

In answer Barabbo bent down, broke off Poomappi's toes, and after first pretending he wanted to juggle them, quickly made them vanish behind his back.

Poomappi was surprised.

- and so on, with more and more atrocious injuries being inflicted for a page and a half, until at last:

The fight was over, at least for the day.

Sometimes the violent energy seems to mangle the language itself:

He grabowerates him and grabacks him to the ground;

He rads him and rabarts him to his drat. ${ }^{18}$

("The Big Fight")

Michaux's dark humor does not only work in mythical, unreal settings. In the texts about Plume-prose narratives three to four pages long-the catastrophes that occur to the 
character come from a widening crack in everyday experience. Thus an embarrassment in a chic restaurant ("the headwaiter came over, looked at him severely and said to him in a low, mysterious voice: 'What you have on your plate is not on the menu'") leads step by step, inexorably, to the police station, where a thuggish cop is promising to work Plume over until he "confesses" -and the text ends there, as a bad dream might. The dreamer survives. Unlike a bad dream, however, it's funny. Besieged by difficulties-- "In a silly moment of distraction, Plume walked with his feet on the ceiling, instead of keeping them on the ground"-Plume blunders through life like a less clever Charlie Chaplin in a more fantastic universe. ${ }^{19}$

If narratives or poems of the self's survival against aggressively hostile forces can be amusing, so can the poet's own superaggressive forays into the world, sinister though they sometimes may be. Take this fairly typical piece from the Plume collection (1938):

\section{THE OAK}

I met an oaktree: as tall as my finger, and it was suffering. Of its four leaves, two were completely yellow. The others were drooping and had no sheen.

I could discover no enemy in the nerghborhood, nor any excessive competition.

Some skullful parasite must have slipped into it. An oak, so what? what's that to a parasite?

So, I ripped it out, root and dead leaves, and up you go!

It's supposed to be tenacious, but to start living again when it was that far gone, no! it hadn't learned enough for that

There is nothing nice about the speaker, or about his world; this could be a terrible little tale of suffering, sickness, death, and destruction. But in fact I enjoy Michaux's reversal here, as he transforms mighty oak into sickly midget. Giants and dwarves everywhere: but the same monstrous metamorphoses and perversions of nature that populate Michaux's Boschlike hells can be used in an entirely different mode. The whole text-especially the narrator's excessive, seemingly pointless rage and triumph — serves as an exorcism through humor; "exorcism through ruse" is the poet's own phrase for many of his works. The demon of rage is cast out through comic exaggeration, and the spell seems to work on the reader, too. 
Just as the mutability of a hollow self swept by raging currents can be eerie and horribly painful_or amusing and pleasant - the transformation of nature and the suspension of its laws has both negative and positive values. We can see this quite clearly in the course of Michaux's explorations "In the Land of Magic" (1941), for example: the master-magicians accomplish both beautiful and terrible things. In a shorter, earlier, text, we find "magic" calming the very anguish that led to its creation:

I used to be quite nervous. Now I'm on a new track: I put an apple on my table. Then I put myself inside the apple. What peace!

This is a recipe for identification with nature which recalls certain techniques of Zen Buddhism, says Michel Butor: ${ }^{20}$ How can we enter into what we see in front of us? How to understand another person from the inside, and not only another person, but an animal_or a fruit? Like Cézanne, who spent years painting apples, Michaux wants to understand that "abyss of tranquillity" from within-no easy task. The poet was distracted from his efforts by the sight of passing women, among other things. It took years:

I had to grope around, experiment--there's quite a story behind all this.

Setting out isn't easy and neither is explaining it.

But I can tell it to you in a word. Sufferng is the word.

When I arrived in the apple, I was ice-cold.

Suffering and ascesis in order to unite oneself with the universe, to reach final peace, "the peace that passeth human understanding" - these are the methods and goals of mystics in many religious traditions, particularly those of Asia.

"Magic," from which we have been quoting, dates from 1938; throughout his career, but increasingly in the last two decades, Michaux's work incorporates what Hinduism, tantric art, and Buddhism (not only Zen Buddhism) have taught him about consciousness, about being. The last two poems in the little anthology that Michaux himself selected for Gallimard in 1976 both bear this mark: "Toward Complete Being" ("Vers la complétude," 1967) and "Yantra" (1973). So do many of the texts in his four major collections from 
1973 to $1985 .{ }^{21}$ If some of their concepts and vocabulary come from the religions of Asia - the cosmogram, the "tantric hand," Purusha-Prakriti, the mandala-they serve to nourish the perennial personal concerns of Henri Michaux. Take the end of this "Outcome of Contemplation":

Silence. The day of silence. Come back to it. Get back inside it. Impermanence has been left behind. As we free ourselves from impermanence, little by little, we find (some more, some less) in our calmed being, progressively, repeatedly deepened, Permanence, its radiance, the other life, the counterlife.

(In Facing the Vanshing World, 1975)

This is not the only place in which Michaux tries to invoke (or create), rhythmically, a state of calm and permanence for the poet's raging, discontinuous self: it is suggested in "Magic" and we find it memorably performed in "To Act, I Come" ( 1949 ), the last section of "Poetry for Power," and elsewhere. So, too, for "the counterlife": the notion is crucial for Michaux from start to finish. Here it is connected to silence; but "the other life" is rooted not only in the religious silence of meditation, but in Michaux's old hostility to all that is fixed, defined-to his hostile distrust of language itself. He himself footnotes "the counterlife" thus: "Alone, without words. Words locate you. You have to reside in the non-located."

The year before he died, Michaux published The Exalted Garden, which is, in my view, the climax of mystic experience in his work. It is a little less than ten pages long and describes, tersely at the start and then in strongly rhythmed, poetic prose, the ecstatic feeling of oneness with the universe that the poet experiences in what is at first an ordinary country garden. It is the transformation and reversal of a Western myth: with an "Eve" as guide rather than temptress, this little space becomes a Garden of Eden, and one ordinary tree becomes something like a new and beautiful Tree of Knowledge. But the text begins, prosaically, "A bit of the prepared product remained." This ecstasy in the Garden is, like By Surprise, which Michaux published in the same year, one of his last texts "about" hallucinogenic drugs.

Again, the drug has acted as a revealer. If it once showed him horrors (horrors he always knew were there), it also taught him that the mind is far vaster than we usually think. For one thing, the mind has in it the capacity to experience infinity-infinity of space and time here and now (see Knowledge through the Abyss, below). Some people have always known 
this without the benefit of drugs; in European literature, Dante is one example. Just before "Toward Complete Being" and "Yantra" at the end of that little 1976 volume of selected poems, Michaux placed an amazing passage from his second "mescaline book," Turbulent Infintty: "I SAW THE THOUSANDS OF GODS." Which gods? "The thousands... " Apparently this is a vision of all the gods in the vast compass of the world's religions - a grandiose claim. Yet it is hard to read the text without thinking that he really saw them, that he "was given that marvelous gift." Religiously inclined or not (and the present writer is not), the reader feels the force of it, with a shock.

It is commonplace--because it is true-to say that great writers can extend our experience. Michaux does it more than most.

\section{David Ball}

\section{NOTES}

I. It was actually written by Breton and Philıppe Soupault (my translation), the first sentence of "Eclipses" in Les Champs magnétiques (1919), a founding Surrealist text.

2 Malcolm Bowie makes this point in Henn Michaux. A Study of His Literary Works (Oxford: Clarendon Press, 1973), 24 Other useful books on Michaux in English.

-Virginia A. La Chanté, Henn Michaux, Twayne's World Authors Series (Boston G. K. Hall, i 977)

-Laurie Edson, Henrt Michaux and the Poetics of Movement (Saratoga, Calif.: Anma Libri, 1985).

-A specral issue of L'Esprit créateur, edited by Laune Edson (v. 26, no. 3, 1986) is devoted to Michaux.

There are fine writungs about his art (and thus indirectly hus poetuc vision) in Henn Mrchaux (New York: The Solomon R Guggenheim Museum, 1978) and in John Ashbery, Reported Sightings (New York: Alfred A. Knopf, 1989).

3. In the Cahters de l'Herne ( 1966 ), Patrick Gregory tells of how Michaux crossed all of Paris to return a pair of gloves to him; Allen Ginsberg relates the polite reception he gave to a couple of young American poets, even when one of them (Gregory Corso) halled hum on the streets of Paris with a "Hey, Henryl" you could hear on the docks of New York. And when I sent Michaux my first fumbling attempts at translating one of his poems years ago, he rephed with a gracjousness that moves me stll.

4 His first book of poetec fictions was called, precisely, Qui je fus (Who I Was [Paris: N.R.F., I 927 ]). But only in the obliquest sense does it live up to its title.

5. As the reader will discover, most of the quotations from Michaux in ths Introduction can be found in the present anthology

6. Michaux rejected Western philosophy: the Chnstian mystics were an exception from the start Later, and more lastingly, he will learn from Eastern mysticism and religion.

7. The dates in this Introduction are those of first publication-_in this case, in Mercure de France Quite often, Michaux will publısh a little text separately as a plaquette, an elegantly printed little book (usually with Fata 
Morgana since the early 1970s), before puttng these works together into an accessible collection (almost invariably with Gallimard)

8 I don't mean Surrealism doesn't interest Michaux; it does, and he writes about the movement, critically, in 1925 , three years after his first published texts. But what he writes and paints himself is usually quite different.

9 Fables des ongines is one of Michaux's first published works (1923). He will write fables-or myths-all his life, as many of the works in this anthology attest

10. The title of a small collection of poems and drawings published in 1946. Some are included in la Vie dans les plss, (Lufe in the Folds r949); see below.

I1. 1943; reprinted in Epreuves, Exorcismes (Ordeals, Exorcisms, 1945). But Michaux's "exorcisms" are by no means limited to one collection

12 In Par des tratts (Through Lines, Fata Morgana, 1984), one of Michaux's last published texts: a hundred or so pages of inked lines (ideograms? little human figures? just lines, squiggles, and blots?), followed by a ten-page essay against "finished languages." As early as $195 \mathrm{l}$, in Mouvements, Michaux had experimented with the possibilities of vaguely suggestive inkbrush strokes "in motion" and words in the accompanying poem. Now, in Through Lanes, he ends with a call for

The sign: finally delivering us from litanies of words, of phrases depending only on phrases, contınung in phrases, it would free the bram from its local over-occupation

Return to a primitive operation whose attraction has been indistinct but is now receiving a new charge

Signs that would enable us to be open to the world differently, creating and developing a different function in man, DISALIENATING HIM.

13. L'Espace du dedans (The Space Withn) is Michaux's title for his I 944 anthology (Gallimard). Richard Ellmann's English translation was first published by New Directions, New York, in 1952.

14. Gilbert Lascault makes this observation in his extremely interesting essay in the Cahrer de l'Herne devoted to Michaux (1966, reprint, Livre de Poche, n.d.)

15. And not in 1956, as he clams in "Some" Information about Fifty-Nine Years of Existence."

16. For the French reader, this is an obvious contrast to Baudelaire's famous Les Paradis artificrels So is the epigraph to Knowledge Through the Abyss, below.

17 I'm quoting André Breton in his Preface to the Anthologre de l'humour norr (1939); he's quotnng Freud. (Reprint, Paris· Jean-Jacques Pauvert, I 966; Livre de Poche, 15; my translation.)

I 8 ll l'emparoulle et l'endosque contre terre,

Il le rague et le roupète jusqu'à son drâle

19. "Our Brother Charlie" was Michaux's contribution on Chaplin to the special issue of the Belgian review Le Disque Vert in 1924, at the beginning of his literary career. "Difficulties" is the title of one group of texts (1930) in the 1938 collection titled Plume

20. Improvisations sur Henri Michaux (Fata Morgana, 1985), 68-69.

21. Moments, traversées du temps (Moments, Crossings of Time, 1973, including work from 1957-1970), Face à ce qui se dérobe (Facing the Vanishing World, 1975); Chemins cherchés chemuns perdus transgressions (Paths Looked-For, Paths Lost, Transgressions, 1981); and the posthumous Déplacements dégagements (Displacements, Disengagements, 1985). 